\title{
PROSES IMITASI ANAK TERHADAP LAGU DEWASA MELALUI NEW MEDIA
}

\author{
Heri Hadiyanto, Ida Ri'aeni, Ahmad Yusron. \\ Program Studi Ilmu Komunikasi \\ Universitas Muhammadiyah Cirebon \\ Jl. Fatahillah N0.40, Watubelah, Cirebon, Jawa Barat, Indonesia \\ herihadiyanto11@gmail.com, ida.riaeni@umc.ac.id, ahmad.yusron@umc.ac.id \\ Submitted: 29 Juni 2020| Accepted: 24 September 2020 | Published: 30 \\ Desember 2020 \\ Website: https://e-journal.umc.ac.id/index.php/jike/index
}

\begin{abstract}
ABSTRAK
Saat ini banyak sekali media massa yang dapat diakses, diantaranya diakses melalui televisi, radio, telepon genggam (smartphone) dan internet, serta peran lingkungan terdekat dalam mempengaruhi perilaku anak. Berdasarkan fenomena tersebut, anak-anak cenderung menyukai lagu dewasa, dan hafal dalam pengucapan liriknya. Penelitian dilakukan terhadap murid sekolah dasar di SD Negeri 17 Kuningan, Jawa Barat. Penelitian ini bertujuan 1) untuk mengetahui faktor stimulus pada anak dalam proses imitasi lagu dewasa, dan 2) untuk mengetahui kognitif dan afektif pada anak dalam proses imitasi lagu dewasa. Metode yang digunakan untuk penelitian ini adalah pendekatan kualitatif dengan tradisi studi kasus, pada penelitannya adalah untuk mengetahui pendekatan atau penelusuran yang bertujuan mengeksplorasi dan memahami suatu gejala sentral. Teknik pengumpulan data dilakukan dengan cara observasi, wawancara, dan dokumentasi. Sedangkan untuk analisis data menggunakan teknik triangulasi.

Berdasarkan hasil penelitian menunjukan bahwa: 1) faktor stimulus pada anak dalam proses imitasi lagu dewasa di SD Negeri 17 Kuningan: (a) media sosial, kecenderungan mendengarkan lagu dewasa melalui YouTube dan Instagram dan durasi yang anak butuhkan anak diantaranya $\leq 1$ jam, 1-3 jam, dan $\geq$ 3 jam. (b) media massa, anak menyaksikan lagu dewasa melalui televisi dari iklan, dan konser. (c) non media/lingkungan, anak terpengaruh lagu dewasa melalui keluarga, kerabat, teman sebaya, lingkungan sekitar tempat tinggal, dan dorongan ingin mengetahui. (d) media sosial yang di akses, keseluruhan anakanak cenderung sering menggunakan YouTube, dan media sosial yang lainnya dalam mengakses lagu dewasa. 2) faktor kognitif dan afektif pada anak dalam proses imitasi lagu dewasa di SD Negeri 17 Kuningan: (a) kognitif, anak cenderung terpapar lagu dewasa dari lingkungan terdekat mereka, di dorong oleh keingintahuan pribadi, sampai akhirnya hafal, akan tetapi anak tidak mengerti arti dan makna lagu yang dimaksud. (b) afektif, berbagai alasan dari mereka menyukai lagu Korea, semata-mata hanya untuk hiburan semata bukan berdasarkan berharap atas pujian orang lain. Dari hasil proses kognitif dan afektif ditemukan tipe-tipe anak yang digolongkan dalam mengimitasi lagu dewasa. (c) behaviorisme/konatif, dampak positif dan negatif dari menyukai lagu dewasa khususnya lagu Korea.
\end{abstract}

Kata Kunci: Proses Imitasi Anak, New Media, Lagu Dewasa, Lagu K-Pop, Teori S-R.

\begin{abstract}
There are many mass media that can be accessed, including being accessed through television, radio, mobile phones (smartphones) and the internet, as well as the role of the closest environment in influencing children's behavior. Based on this phenomenon, children tend to like adult songs, and memorize the pronunciation of the lyrics. The study was conducted on elementary school students in SD Negeri 17 Kuningan, West Java. This study aims at 1) to find out the stimulus factors in children in the process of imitation of adult songs, and 2) to find out cognitive and affective in children in the process of imitation of adult songs. The method used for this study is a qualitative approach with a case study tradition, in this research is to find out approaches or searches that aim to explore and understand a central phenomenon. Data collection techniques are carried out by observation, interviews, and documentation. While for data analysis using triangulation techniques.
\end{abstract}


Based on the results of the study show that: 1) stimulus factors in children in the process of imitation of adult songs in Kuningan 17 Public Elementary School: (a) social media, the tendency to listen to adult songs via YouTube and Instagram and the duration that children need among them $\leq 1$ hour, $1-3$ hours, and $\geq 3$ hours. (b) mass media, children watch adult songs through television from advertisements, and concerts. (c) non-media / environment, children affected by adult songs through family, relatives, peers, the environment around the residence, and encouragement to know. (d) social media that is accessed, all children tend to often use YouTube, and other social media in accessing adult songs. 2) cognitive and affective factors in children in the process of imitation of adult songs in Kuningan 17 Public Elementary School: (a) cognitive, children tend to be exposed to adult songs from their closest environment, driven by personal curiosity, until finally memorized, but children do not understand the meaning and the meaning of the song in question. (b) affective, various reasons for their liking Korean songs, solely for purely entertainment rather than based on wishing for the praise of others. From the results of cognitive and affective processes found the types of children that are classified in imitating adult songs. (c) behaviorism / konatif, positive and negative effects of liking adult songs, especially Korean songs.

Keywords: Imitation Children Process, New Media, Adults Song, K-Pop Songs, S-R Theory. 


\section{A.PENDAHULUAN}

Media massa dalam peranannya adalah memberikan suatu informasi kepada khalayak yaitu masyarakat sebagai komunikan, sudah semestinya media menyajikan sajian yang berupa berita yang informatif serta mendidik kepada para khalayak yang menjadi objek sasaran dari media tersebut. Akan tetapi seiring berkembangnya zaman, saat ini media semakin mengalami banyak perkembangan, yang dibarengi dengan kemajuan teknologi yang terjadi, dan semakin mudah orang mengakses suatu informasi.

Banyak sekali media massa yang dapat diakses saat ini, diantaranya diakses melalui televisi, radio, telepon genggam (smartphone) dan internet. Ditambah dengan banyaknya penggunaan smartphone saat ini yang didukung dengan tersedianya berbagai fitur layanan dan aplikasi-aplikasi yang mendukung untuk orang lebih mudah untuk mendapatkan informasi terbaru dan up to date.

Namun saat ini banyak sekali media yang menyajikan selain berita yang sifatnya informatif, mereka menyajikan bentuk hiburan untuk memanjakan para pendengar dan penontonnya, yang hal ini dapat banyak ditemukan di media elektronik seperti televisi dan radio. Banyak khalayak yang terhibur akan sajian jadwal acara yang ada, tetapi dalam penayangan atau penyiarannya banyak sekali hal yang tidak diperdulikan media adalah sangat minimnya acara-acara yang sifatnya edukatif untuk konsumsi yang di sini adalah anak-anak sebagai penikmat acara. Sangat kurangnya tayangan atau siaran yang pantas untuk anak-anak se-usia mereka, yang dikhawatirkan bagi anak-anak yang melihatnya akan berdampak negatif bagi mereka.

Ditambah dengan pola perilaku orang-orang di lingkungan yang diantaranya orangorang terdekat mereka seperti teman-temannya, dan termasuk keluarganya, yang dalam perilakunya anak-anak cenderung diperkenalkan dengan oleh hal-hal yang yang tidak seharusnya anak-anak ketahui untuk batasan se-usia mereka. Menurut Campbell dalam Budi (2016: 1) mengatakan:

"Kemampuan menginterpretasikan keberadaan interval untuk bahasa dan musik hanya ada dan mulai ketika bayi berinteraksi dengan lingkungan dan orang-orang dekatnya."

Karena ini akan menjadi suatu permasalahan yang akan terjadi nantinya. Anak-anak yang notabene pada masa-masa tersebut, mereka cenderung untuk meniru sesuatu yang langsung mereka saksikan sendiri baik itu melalui indra pendengaran, maupun indera pengelihatan mereka. Kegiatan suatu peniruan saat ini banyak terjadi, khususnya pada 
anak-anak yang coba menyesuaikan dirinya untuk menyukai suatu tayangan atau siaran yang disajikan, tanpa menyadari dirinya belum saatnya untuk mengetahui sajian yang pantas untuk dilihat atau didengarnya.

Fenomena yang sering banyak terjadi saat ini adalah fenomena yang dialami oleh anak-anak. Mereka cenderung menyukai lagu dewasa, dan hafal dalam pengucapan liriknya. Anak-anak adalah peniru paling utama, mereka meniru hal-hal apa saja yang mereka rasakan oleh panca inderanya.

Sejalan dengan fenomena yang ada. Dilansir dari (sindonews.com) menurut Dian Fitriaswaty psikolog anak dan remaja, anak adalah peniru ulung dan di masa anak-anak, segala informasi begitu mudah diserap. Jika lagu-lagu yang dinyanyikan berlirik dengan yang tidak mendidik tentu sangat mempengaruhi tumbuh kembangnya anak. Anak akan belajar kata-kata yang seharusnya hanya pantas diucapkan orang dewasa seperti kata-kata di dalam lirik lagu-lagu cinta yang marak di Indonesia.

Dian mengatakan "Bahayanya anak akan mudah menerapkan romantisme di usianya yang belum pantas untuk itu," Psikolog di Klinik Dokter Keluarga Fakultas Kedokteran Universitas Brawijaya, Selasa (23/9/2014). Idealnya, anak harus memiliki banyak aktivitas fisik untuk mengasah berbagai perkembangan psikologisnya, diantaranya berupa permaianan-permainan fisik, olahraga, kesenian, yang seharusnya mendominasi aktivitas anak di luar sekolah. "Bukan banyak menonton televisi."

Sebelumnya peneliti telah melakukan sebuah observasi secara langsung, melalui pendekatan ke beberapa anak-anak yang tengah mengikuti kegiatan Car Free Day pada hari minggu pagi di Kota Cirebon, peneliti melakukan obrolan ringan kepada ketiga anak yang saat itu sedang melakukan kegiatan menggambar. Di sela-sela obrolan ringan yang dilakukan, dengan mengajukan pertanyaan keingintahuan peneliti tentang kesukaan ketiga orang anak-anak tersebut, khususnya menanyakan lagu apa yang anak-anak sukai atau yang paling mereka dengarkan. Akhirnya berdasarkan yang peneliti ketahui setelah mengajukan beberapa pertanyaan yang ditujukan kepada ketiga anak tersebut, diketahui bahwa ketiganya sangat menyukai lagu-lagu korea yang sering mereka dengarkan, sedangkan untuk lagu lain yang sedang populer saat itu adalah lagu ber gendre dangdut yang berjudul "Lagi Syantik" yang dipopulerkan oleh penyanyi Siti Badriah asal Indonesia.

Peneliti juga menanyakan perihal judul lagu anak-anak apa yang pernah mereka dengar atau yang mereka ketahui, didapatkan jawaban bahwa yang mereka sering dengar 
adalah lagu "Balonku" dan lagu "Becak" yang itu pun menurut mereka lagu "Becak" sendiri mereka mengetahuinya berdasarkan dari buku LKS yang diajarkan di sekolah. Peneliti merasa miris akan jawaban yang telah dikatakan oleh anak-anak tersebut.

Dalam hal ini peneliti memilih anak-anak sebagai objek peneliti, dan menurut pembagian usia bisa dikatakan sebagai anak-anak adalah usia 6-12 tahun. Untuk mengetahui tahapan tentang gambaran pertumbuhan manusia dari masa kanak-kanak hingga remaja, Menurut Sujanto (1996) dalam Ma'ruf (2016: 13) membagi tahapan sebagai berikut:

"Pertama, masa kanak-kanak, yaitu sejak lahir sampai 5 tahun kedua, masa anak, yaitu umur 6 sampai 12 tahun ketiga, masa pubertas, yaitu umur 13 tahun sampai kurang lebih 18 tahun bagi anak putri dan sampai umur 22 tahun bagi anak putra keempat, masa adolesen, sebagai masa transisi kemasa dewasa."

Untuk kategori subjek penelitian, peneliti melakukan penelitian terhadap anak usia 6-12. Sedangkan untuk penetapan kelas berdasarkan usia yang telah ditentukan, peneliti menentukan kelas 3 dan 4 sebagai kelas yang akan diteliti. Alasan peneliti memilih penentuan subjek tersebut, karena usia 6-12 tahun adalah kategori sebelumnya telah dijelaskan, pada masa tersebut disebut masa anak-anak, kemudian jika melihat dari sudut pandang peneliti menentukan kelas 3 dan 4 adalah, dalam kategori kelas yang dipilih tersebut peneliti beranggapan bahwa pada kelas tersebut dipilih karena dalam usia tersebut anak sudah mulai berpikir nalar mengenai objek yang ada di hadapannya.

Peneliti memilih locus tempat penelitian bertempat di SDN 17 Kuningan. Alasan penelitian dilakukan di tempat tersebut adalah karena dilihat dari kondisi geografis tata letak sekoah tersebut dekat dengan pusat Kota Kuningan. Ditambah pergaulan yang mayoritas masyarakat perkotaan yang cenderung mengikuti perkembangan zaman akan modernisasi.

Kemudian peneliti melakukan tahap pra-riset pada tanggal 10-11 Januari 2019, di SD Negeri 17 Kuningan, untuk mengetahui lagu apa yang sedang populer di tempat itu. Setelah peneliti melakukan pra-riset dan melakukan sedikit wawancara pada anak-anak, didapatkan data bahwa anak kelas 3C dan 4A mayoritas untuk anak-anaknya lebih menyukai lagu Kpop sebagai lagu kesukaan mereka, seperti BTS, EXO, BlackPink, dan lainnya. Khususnya untuk mayoritas anak perempuan dan laki-laki walaupun hanya beberapa orang saja. 
Dalam penelitian penelitian ini, peneliti menggunakan teori S-O-R atau StimulusOrganism-Response, menurut Mar'at (1984) dalam Ardianto (2010: 134) Teori S-O-R menitikberatkan pada proses pengertian yang banyak menyangkut komponen kognisi. Dalam hal ini stimulus respons (S-R), masalah kognisi lebih diutamakan, sedangkan komponen afeksi diabaikan, sementara komponen konasi tergantung pada imbalan (ganjaran) dan hukuman sebagai akibat dari penguatan rangsangan. Di dalam pendekatan teori S-O-R diutamakan cara-cara pemberian imbalan yang efektif agar komponen konasi dapat diarahkan pada sasaran yang dikehendaki. Sedangkan pemberian informasi adalah sesuatu yang penting untuk dapat mengubah komponen kognisi.

Teori ini menggambarkan "perubahan sikap", bergantung pada proses yang terjadi pada individu:

1. Stimulus yang diberikan pada organisme dapat diterima atau ditolak. Jika stimulus ditolak organisme, pada proses selanjutnya terhenti. Ini berarti bahwa stimulus tersebut tidak efektif dalam memengaruhi organisme sehingga tidak ada perhatian (attention) dari organisme. Jika stimulus diterima oleh organisme, berarti adanya komunikasi dan perhatian dari organisme. Dalam hal ini stimulus efektif dan ada reaksi.

2. Jika stimulus telah mendapat perhatian dari organisme, proses selanjutnya adalah mengerti terhadap stimulus (correctly comprehended). Kemampuan dari organisme inilah yang dapat melanjutkan proses berikutnya.

3. Pada langkah berikutnya adalah organisme dapat menerima secara baik apa yang telah diolah sehingga terjadi kesediaan untuk perubahan sikap.

Menurut Mar'at (1984) dalam Ardianto (2010: 135) Dalam proses perubahan sikap ini terlihat bahwa sikap dapat berubah jika rangsang yang diberikan benar-benar melebihi rangsang semula. Stimulus yang disampaikan pada organisme akan dijawab dengan adnya perhatian terhadap isi. Pada proses-proses ini terdapat kegiatan-kegiatan dari komponen kognisi yang memberikan informasi mengenai stimulus tersebut. Informasi ini diproses melalui proses belajar berdasarkan pengalaman. Informasi tersebut pada awalnya belum mempunyai arti, baru sampai pada taraf introspektif.

\section{B. TINJAUAN PUSTAKA}

Berikut ini adalah fase-fase dalam perkembangan dalam kehidupan manusia, di antaranya: 


\section{a. Fase Perkembangan Menurut Erikson}

Erikson berpendapat dalam Hamdi (2016: 57-67) menyatakan bahwa ada delapan tahap perkembangan bukan lima tahap seperti yang dikemukakan Freud. Erikson merinci tingkat "genital" Freud pada fase remaja plus tiga tingkat masa dewasa. Erikson punya beberapa pemikiran tentang interaksi dari generasi yang disebut dengan "mutually." Freud mengemukakan bahwa orang tua berpengaruh pada perkembangan anaknya yang bersifat dramatik. Erikson menjelaskan bahwa perkembangan anak yang dipengaruhi oleh orang tua adalah baik. Berikut adalah tabel tahapan perkembangan menurut Erikson:

Tabel 1. Tahap Perkembangan Menurut Erikson

\begin{tabular}{|c|c|c|c|c|c|}
\hline $\begin{array}{l}\text { Tahap } \\
\text { (Usia) }\end{array}$ & $\begin{array}{l}\text { Krisis } \\
\text { Psikososi } \\
\text { al }\end{array}$ & \begin{tabular}{|l} 
Lingkun \\
gan \\
Sosial \\
Utama \\
\end{tabular} & $\begin{array}{l}\text { Model } \\
\text { Psikososial }\end{array}$ & $\begin{array}{l}\text { Virtue } \\
\text { Psikososial }\end{array}$ & $\begin{array}{l}\text { Maladaption } \\
\text { \& } \\
\text { Malignancie } \\
\text { s }\end{array}$ \\
\hline $\begin{array}{l}\text { I }(0-1) \\
\text { Bayi }\end{array}$ & $\begin{array}{l}\text { Trust vs } \\
\text { mistrust }\end{array}$ & Ibu & $\begin{array}{l}\text { Mengambil, } \\
\text { mengembali } \\
\text { kan }\end{array}$ & $\begin{array}{l}\text { Harapan } \\
\text { Kepercayaan }\end{array}$ & $\begin{array}{l}\text { Sensory } \\
\text { distortion } \\
\text { withdrawal }\end{array}$ \\
\hline $\begin{array}{l}\text { II (2-3) } \\
\text { Awal } \\
\text { Anak }\end{array}$ & $\begin{array}{l}\text { Autonom } \\
\text { y vs } \\
\text { shame, } \\
\text { doubt }\end{array}$ & $\begin{array}{l}\text { Orang } \\
\text { Tua }\end{array}$ & $\begin{array}{l}\text { Mempertaha } \\
\text { nkan, } \\
\text { merelakan }\end{array}$ & $\begin{array}{l}\text { Keinginan, } \\
\text { penentuan }\end{array}$ & $\begin{array}{l}\text { Impulsivity } \\
\text { comupulsion }\end{array}$ \\
\hline $\begin{array}{l}\text { III (3-6) } \\
\text { Prasekola } \\
\text { h }\end{array}$ & $\begin{array}{l}\text { Initative } \\
\text { vs guilt }\end{array}$ & Keluarga & Bermain & $\begin{array}{l}\text { Kegunaan, } \\
\text { keberanian }\end{array}$ & $\begin{array}{l}\text { Ruthlessness, } \\
\text { inhibition }\end{array}$ \\
\hline $\begin{array}{l}\text { IV (7-12 } \\
\text { atau } \\
\text { lebih) } \\
\text { Usia } \\
\text { Sekolah }\end{array}$ & $\begin{array}{l}\text { Industry } \\
\text { vs } \\
\text { isolation }\end{array}$ & $\begin{array}{l}\text { Tetangga } \\
\text { dan } \\
\text { Sekolah }\end{array}$ & $\begin{array}{l}\text { Melengkapi } \\
\text { membuat } \\
\text { sesuatu } \\
\text { bersama }\end{array}$ & Kompetensi & $\begin{array}{l}\text { Narrowvirtou } \\
\text { sinertia }\end{array}$ \\
\hline $\begin{array}{l}\mathrm{V}(12-18 \\
\text { atau } \\
\text { lebih) } \\
\text { Remaja }\end{array}$ & $\begin{array}{l}\text { Ego } \\
\text { identity } \\
\text { vs role } \\
\text { confusion }\end{array}$ & $\begin{array}{l}\text { Teman } \\
\text { Sebaya, } \\
\text { role } \\
\text { models }\end{array}$ & $\begin{array}{l}\text { Menjadi diri } \\
\text { sendiri }\end{array}$ & $\begin{array}{l}\text { Ketaatan, } \\
\text { kesetiaan }\end{array}$ & $\begin{array}{l}\text { Fanaticism } \\
\text { repudiation }\end{array}$ \\
\hline
\end{tabular}




\begin{tabular}{|l|l|l|l|l|l|}
\hline $\begin{array}{l}\text { VI (20) } \\
\text { Dewasa } \\
\text { Awal }\end{array}$ & $\begin{array}{l}\text { Intimacy } \\
v s \\
\text { isolation }\end{array}$ & $\begin{array}{l}\text { Partner, } \\
\text { Teman }\end{array}$ & $\begin{array}{l}\text { Kehilangan } \\
\text { dan } \\
\text { menemukan } \\
\text { diri dalam } \\
\text { orang lain }\end{array}$ & Cinta & $\begin{array}{l}\text { Promiseuty } \\
\text { exclusivity }\end{array}$ \\
\hline $\begin{array}{l}\text { VII (20- } \\
\text { 50) } \\
\text { Dewasa } \\
\text { Madya }\end{array}$ & $\begin{array}{l}\text { Generati } \\
\text { vity vs } \\
\text { self } \\
\text { absorptio } \\
n\end{array}$ & $\begin{array}{l}\text { Rumah } \\
\text { Tangga, } \\
\text { Teman } \\
\text { Kerja }\end{array}$ & $\begin{array}{l}\text { Ingin suatu } \\
\text { hal terjadi, } \\
\text { menjaga }\end{array}$ & Kepedulian & $\begin{array}{l}\text { Overextensio } \\
n \text {, penolakan }\end{array}$ \\
\hline $\begin{array}{l}\text { VIII (50) } \\
\text { Usia Tua }\end{array}$ & $\begin{array}{l}\text { Integrity } \\
\text { vs } \\
\text { despire }\end{array}$ & $\begin{array}{l}\text { Kehidupa } \\
\mathrm{n} \\
\text { Manusia }\end{array}$ & $\begin{array}{l}\text { To be } \\
\text { through } \\
\text { having been, } \\
\text { to be face } \\
\text { not being }\end{array}$ & $\begin{array}{l}\text { Kebijaksanaa } \\
\mathrm{n}\end{array}$ & $\begin{array}{l}\text { Kesombonga } \\
\text { n, putus asa }\end{array}$ \\
\hline
\end{tabular}

Sumber: Hamdi (2016: 58)

Sebagai pembanding, Charlotte Buhler (1930) dalam bukunya The First Tear of Life, (Sobur, 2016: 117-118) membagi fase perkembangan sebagai menjadi Fase Pertama (0-1 Tahun), Fase Kedua (2-4 Tahun), Fase Ketiga (58 Tahun), Fase Keempat (9-11 Tahun), dan Fase Kelima (14-19 Tahun).

\section{Teori S-O-R}

Dikutip dari Effendy (2003: 254) Teori S-O-R sebagai singkatan dari Stimulus-Orgnism-Response ini semua berasal dari psikologi. Kalau kemudian menjadi juga teori komunikasi, tidak mengherankan, karena objek material dan psikologi dan ilmu komunikasi adalah sama, yaitu manusia yang jiwanya meliputi komponen-komponen: sikap, opini, perilaku, kognisi, afeksi dan konasi.

Menurut stimulus response ini, efek yang ditimbulkan seseorang adalah reaksi khusus terhadap stimulus khusus, sehingga seseorang dapat mengharapkan dan memperkirakan kesesuaian antara pesan dan reaksi komunikan. Jadi unsurunsur dalam model ini adalah: Pesan (Stimulus, S); Komunikan (Organism, O) dan Efek (Response, R). Dalam proses komunikasi berkenaan dengan perubahan sikap 
adalah aspek "how" bukan "what" dan "why." Jelasnya how to communicate dalam hal ini how to change the attitude, bagaimana mengubah sikap kemungkinan. Dalam perubahan sikap tampak bahwa sikap dapat berubah hanya jika stimulus yang menerpa benar-benar melebihi semula.

Menurut Mar'at dalam bukunya "Sikap Manusia, Perubahan serta Pengukurannya," yang mengutip pendapat Hovland, Janis, dan Kelley dalam Effendy (2003: 255) menyatakan bahwa dalam menelaah sikap yang baru ada tiga variabel penting, yaitu: Perhatian; Pengertian; dan Penerimaan.

\section{Gambar 2. Teori S-O-R}

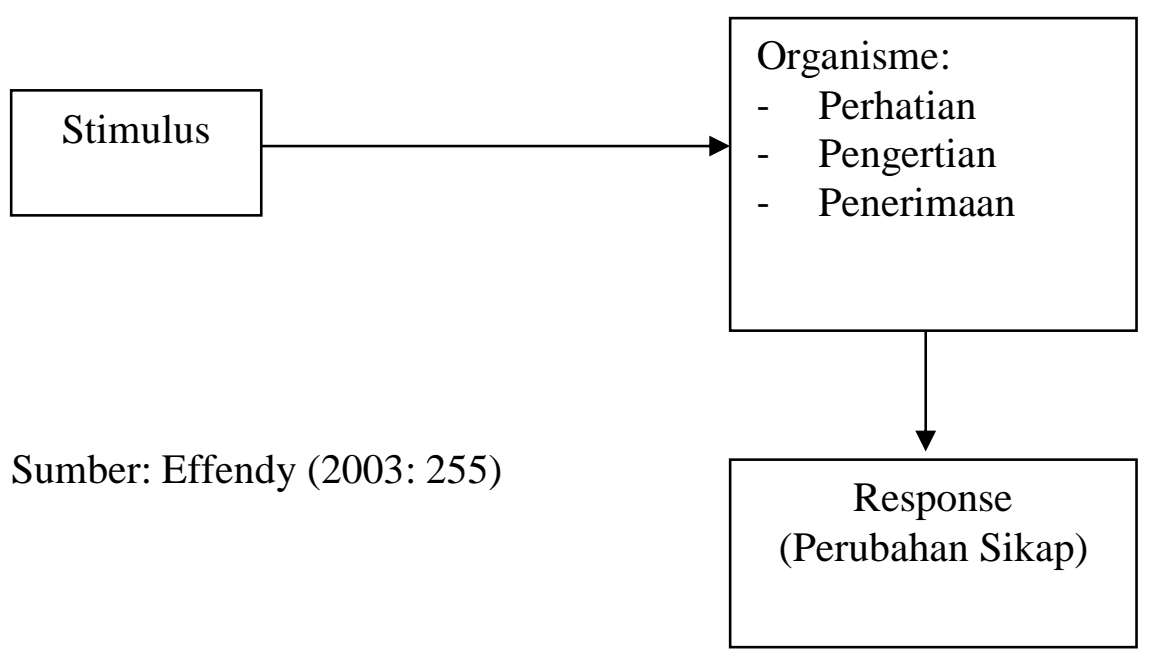

Gambar 2 di atas menunjukan bahwa perubahan sikap bergantung pada proses yang terjadi pada individu.Stimulus atau pesan yang disampaikan kepada komunikan mungkin diterima atau mungkin ditolak. Komunikasi akan berlangsung jika ada perhatian dari komunikan. Proses berikutnya komunikan mengerti. Kemampuan komunikan inilah yang melanjutkan proses berikutnya. Setelah komunikan mengolah datanya dan menerimanya, maka terjadilah kesediaan untuk mengubah sikap.

Gambar 3. Kerangka Penelitian Proses Imitasi Anak

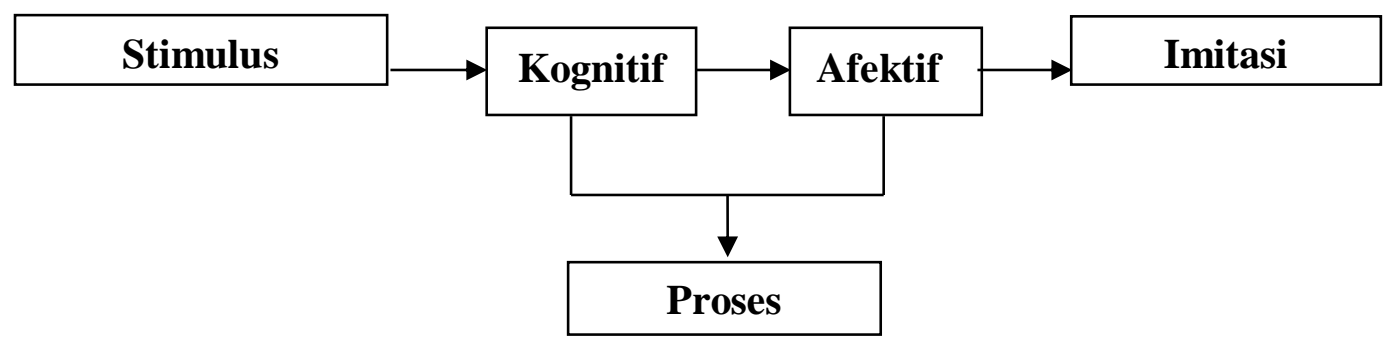


Gambar 3 di atas menjelaskan tahap stimulus adalah proses imitasi tahap awal anak terangsang dan mengenal objek untuk pertama kalinya. Tahap Proses imitasi lanjutan, dimana objek diterima selanjutnya mempengaruhi kognitif dan afektif anak. Tahap terakhir adalah imitasi, sebuah produk atau hasil yang dihasilkan akan efek atau dampak atas imitasi yang dialami anak.

\section{C.METODOLOGI PENELITIAN}

Dalam penelitian dibutuhkan suatu metode dalam memudahkan sebuah penelitian. Menurut Winarno Surakhmad (1998: 131) dalam Mulyadi (2016: 28) menyatakan bahwa:

"Metode merupakan cara utama yang dipergunakan untuk mencapai tujuan, misalnya untuk menguji serangkaian hipotesis dengan mempergunakan teknik serta alat tertentu. Cara itu dipergunakan setelah penyelidik memperhitungkan kewajarannya ditinjau dari penyelidikan serta situasi penyelidikan."

Metode yang digunakan dalam penelitian ini adalah metode kualitatif. Menurut Creswell (1994) dikutip dari Semiawan (2010: 7) mendefinisikannya sebagai suatu pendekatan atau penelusuran untuk mengeksplorasi dan memahami suatu gejala sentral. Untuk mengerti gejala sentral tersebut peneliti mewawancarai peserta penelitian atau partisipan dengan mengajukan pertanyaan yang umum dan agak luas.

Pendekatan yang digunakan dalam penelitian ini adalah dengan menggunakan tradisi studi kasus yang menurut Semiawan (2010: 50) studi kasus ini dapat membantu peneliti untuk mengadakan studi mendalam tentang perorangan, kelompok, program, organisasi, budaya, agama, daerah atau bahkan negara.

\section{a. Pemilihan Informan}

Berikut adalah beberapa data informan-informan yang dianggap memenuhi dalam kriteria yang diperlukan dalam penelitian. Adapun informan tersebut adalah:

1. Anak-anak, sebagai narasumber utama. Berikut ini adalah kualifikasi pemilihan informan anak-anak tersebut.
a. Siswi kelas 3 dan 4 di SD Negeri 17 Kuningan;
b. Siswi dengan usia 6-12 tahun;
c. Siswi yang memiliki minat terhadap lagu Korea;
d. Siswi yang cenderung mengikuti perkembangan lagu. 
2. Wali Murid/Orang Tua, sebagai narasumber pendukung.Berikut ini adalah kualifikasi pemilihan informan wali murid/orang tua tersebut.

a. Wali murid/orang tua dari siswi SD Negeri 17 Kuningan;

b. Wali murid/orang tua dari dari siswi kelas 3 atau 4 di SD Negeri 17 Kuningan;

c. Wali murid/Orang tua dari siswi yang menjadi narasumber utama.

3. Guru, sebagai narasumber pendukung. Berikut ini adalah kualifikasi pemilihan informan guru

a. Guru wali kelas 3 dan 4 di SD Negeri 17 Kuningan.

Dalam penelitian ini peneliti menggunakan metode prosedur kuota, seperti yang dijelaskan oleh Bungin (2011: 108) bahwa prosedur ini, kadang-kadang dianggap sebagai jenis prosedur purposif. Dalam prosedur kuota, peneliti memutuskan saat merancang penelitian, berapa banyak orang dengan karakteristik yang diinginkan untuk dimasukkan sebagai informan. Karakteristik mungkin termasuk usia, tempat tinggal, jenis kelamin, kelas, profesi, status perkawinan. Kriteria yang dipilih memungkinkan peneliti untuk fokus pada orang yang peneliti perkirakan akan paling mungkin memiliki pengalaman, tahu tentang, atau memiliki wawasan ke dalam topik penelitian. Peneliti pergi ke masyarakat lalu menggunakan strategi rekrutmen yang tepat untuk lokasi, budaya, dan populasi penelitian menemukan orang yang sesuai dengan kriteria ini, sampai peneliti memenuhi kuota yang ditentukan.

\section{HASIL DAN PEMBAHASAN}

Sekolah Dasar Negeri 17 Kuningan yang berada di pusat kota Kabupaten Kuningan. SD ini adalah semula SD Negeri 1 Kuningan yang merupakan SD berstandar Nasional (SD SN) dan SD Negeri 7 Kuningan (SD unggulan). Prestasi kedua sekolah ini adalah dalam bidang akademik, pengembangan kesenian Sunda, dan pengembangan kerajinan membatik serta Marching Band. Setelah SD Negeri 1 Kuningan merger dengan SD Negeri 7 Kuningan nama sekolah berdasarkan SK Bupati Kuningan nomor: 421.2/KPTS.546-Disdikpora/2012) terhitung 1 Februari 2013 menjadi SD Negeri 17 Kuningan. Setelah. Akan tetapi efektif penyatuan 2 sekolah setelah adanya kepala 
sekolah baru mulai akhir Maret 2013. Keunggulan sekolah sampai sekarang dalam bidang akademik (Calistung, OSN, Bahasa Inggeris; FLSSN), pengembangan kesenian daerah (Pskab), keterampilan membatik, dan Marching Band.

Berdasarkan penelitian yang telah peneliti lakukan di lapangan, peneliti akan uraikan hasil temuan yang didapat. Penelitian dilakukan yang bertempat di SD Negeri 17 Kuningan, Kecamatan Kuningan, Kabupaten Kuningan, dengan judul "Proses Imitasi Anak Terhadap Lagu K-Pop Melalui New Media." Sebelum diuraikan hasil dari penelitian yang telah dilakukan, sebelumnya peneliti akan terlebih dahulu menjabarkan beberapa kriteria data dan unit analisis yang digunakan meliputi sebagai berikut: (1) Stimulus: Media: media Sosial atau Media Massa; Non Media/Lingkungan, dan jenis Media Habit yang Diakses. (2)Faktor Kognitif dan Afektif.

Kemudian berdasarkan penjabaran beberapa kriteria data dan unit analisis tersebut, langkah selanjutnya peneliti melakukan konfirmasi kepada informan-informan yang menjadi subjek penelitian. Berikut adalah informan-informan dalam penelitian ini, diantaranya anak-anak siswi kelas 3 dan 4 dengan kualifikasi 6-12 tahun, orang tua siswi kelas 3 atau 4, guru atau wali kelas 3 dan 4.

\section{Proses Stimulus pada Anak dalam Proses Imitasi Lagu Dewasa di SD Negeri 17 Kuningan}

Berdasarkan deskripsi hasil penelitian, peneliti memberikan uraian yang berisi penjelasan masalah dari proses stimulus pada anak yang akan disajikan dalam bagan berikut:

\section{Gambar 4. Proses Imitasi Stimulus Anak}

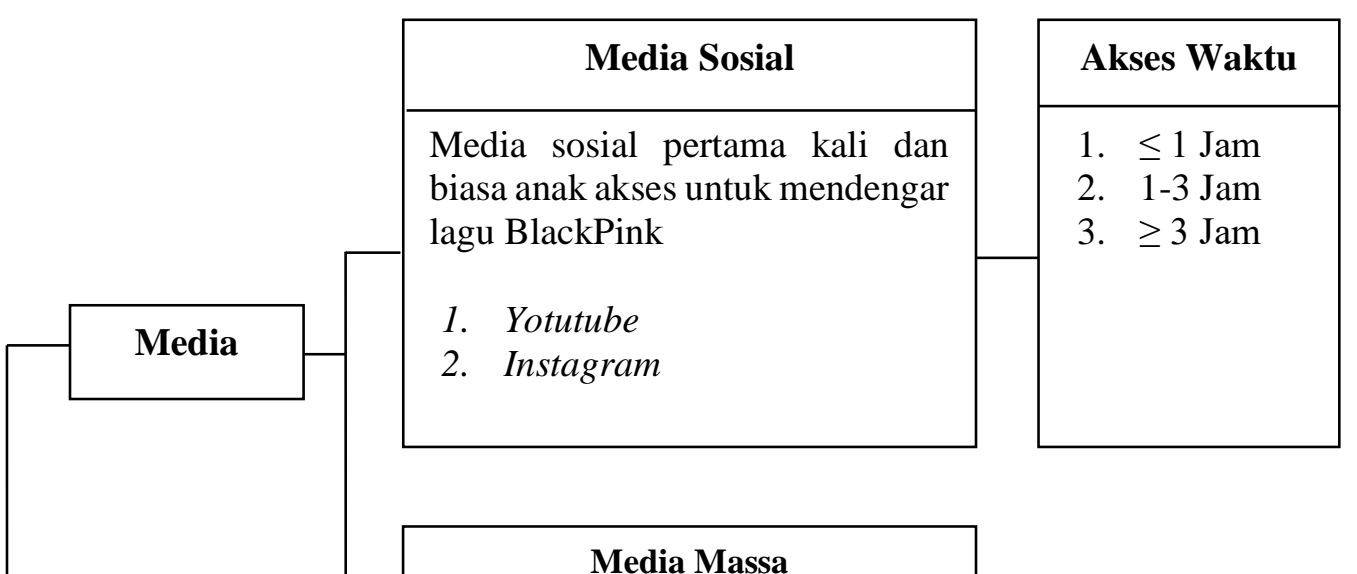


Gambar 4 di atas menjelaskan, dari data stimulus yang telah diuraikan, didapatkan hasil penelitian dari proses stimulus terhadap lagu BlackPink diantaranya adalah: 1. Media: 1) media sosial: media sosial yang pertama kali digunakan dan biasa digunakan untuk mengakses lagu BlackPink adalah (1) YouTube dan (2) Instagram, akses waktu yang biasa dipakai anak (1) $\leq 1$ Jam, (2) 1-3 Jam, dan (3) $\geq 3$ Jam. 2) media massa: media massa yang digunakan untuk mengakses lagu BlackPink dari televisi dan menyaksikannya melalui (1) iklan, dan (2) konser yang ditayangkan. 2. Lingkungan: 1) faktor internal: faktor dari dalam diri pribadi anak yang ternyata justru sebagai orang yang mempengaruhi baik itu kepada kakak perempuannya maupun adiknya dalam 
mengenalkan lagu BlackPink, 2) faktor eksternal: faktor yang dipengaruhi dari luar pribadi anak tersebut atau lingkungan sekitar tempat anak itu berada dalam diantaranya adalah (1) kakak perempuan, (2) pengaruh teman, (3) pengaruh tetangga yang menempati lingkungan sekitar dimana dekat anak tersebut tinggal.

\section{a. Media Habit yang Diakses}

Dalam penggunaan media sosial/aplikasi internet sendiri yang biasa anak-anak gunakan pada saat mendownload/mengunduh lagu BlackPink khususnya pada anak perempuan di SD Negeri 17 Kuningan, biasanya anakanak menggunakan YouTube sebagai aplikasi video streaming sekaligus sebagai media sosial/aplikasi mendownload/mengunduh video klip lagu Korea untuk mereka saksikan dan mereka dengarkan, kemudian dari Search Google, lalu ada juga yang melalui website unduhan lagu gratis, dan ada juga aplikasi lain untuk mengunduh lagu BlackPink diantaranya salah satunya yaitu aplikasi Snaptube.

Sedangkan untuk media sosial/aplikasi internet yang biasanya temantemannya akses untuk mendengarkan lagu BlackPink adalah melalui media sosial/aplikasi YouTube sebagai media sosial/aplikasi rata-rata temantemannya akses sampai saat ini.

Berdasarkan deskripsi hasil penelitian di atas, untuk itu peneliti akan memberikan uraian yang berisi penjelasan masalah dari media sosial yang di akses oleh anak yang akan disajikan dalam bagan berikut:

\section{Gambar 5. Media Habit yang Diakses}




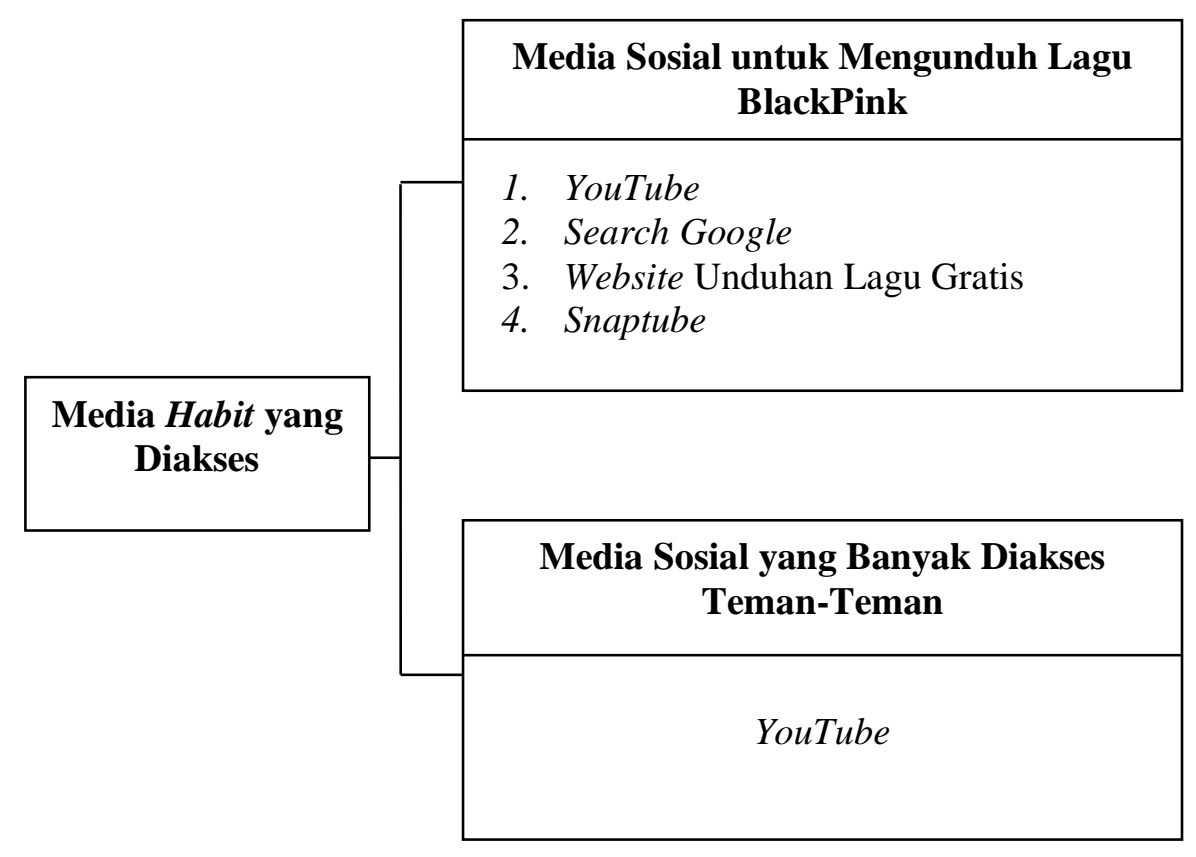

Gambar 5 di atas menjelaskan, dari data media sosial yang di akses yang telah diuraikan, didapatkan hasil penelitian dari data media sosial yang anakanak sering akses untuk mendengarkan dan menyaksikan lagu, khususnya lagu BlackPink antara lain: 1. Media sosial yang mereka gunakan untuk mengunduh lagu diantaranya adalah: (1) YouTube, (2) Search Google, (3) Website unduhan lagu gratis, (4) Snaptube. 2. Media sosial yang banyak/mayoritas teman-temannya gunakan untuk mendengarkan lagu, diantaranya adalah: YouTube.

2. Kognitif dan Afektif pada Anak dalam Proses Imitasi Lagu Dewasa di SD Negeri 17 Kuningan

\section{a. Kognitif}

Dalam pengaruh secara kognitif anak-anak, ternyata didapatkan bahwa anak-anak pertama kali mendengar atau melihat lagu BlackPink khususnya siswi di SD Negeri 17 Kuningan mendapatkan pengaruh secara kognitif adalah dari temannya, walaupun diantara yang lainnya ada juga yang dalam dirinya terselip keinginan rasa ingin tahu dan mencari di YouTube sampai dengan akhirnya bisa menyukai atau menggemari lagu Korea dalam hal ini adalah lagu BlackPink, lalu ada salah satunya lagi mengungkapkan keluarga 
juga mempunyai andil dalam mempengaruhi mereka untuk menyukai lagu BlackPink baik secara langsung maupun secara tidak langsung dan salah satunya melalui kakak perempuannya, dan juga ternyata dia mengetahui lagu BlackPink berasal dari rumah saudaranya saat mengunjungi rumah saudaranya sendiri. Masih dengan hal yang serupa tentang pengaruh dari teman-temannya dalam hal mengimitasi, ini sesuai dengan yang dijelaskan menurut Gabriel Tarde dalam Gerungan (2004:33) dalam Sofianita dan Harti (2015) berpendapat bahwa semua saling berhubungan sosial (sosial interaction) itu berkisar pada proses imitasi, bahkan semua pergaulan antarmanusia itu menurut pendapat ini hanyalah proses imitasi itu. Imitasi adalah contoh-mencontoh, tiru-meniru, ikut-mengikuti, dan perkembangan proses imitasi dalam masyarakat sebagai rangsangan pikiran. Maka hal-hal yang diimitasi itu harus mendapat perhatian individu terlebih dahulu agar dapat di imitasi, selanjutnya terdapat sikap menjunjung tinggi atau mengagumi hal-hal yang akan diimitasi. Dan terdapat pengertian yang cukup pada orang-orang terhadap hal-hal yang akan diimitasi itu, dan hal ini bergantung pula kepada tingkat perkembangan individu, kepada taraf intelejensinya dan kepribadian pada umumnya. Teman sebaya termasuk di dalamnya karena salah satu pendorong untuk memasuki suatu kelompok agar kita diterima oleh di dalam lingkungan mereka kita harus bergaya seperti mereka, mengikuti perilaku sosial remaja, sehingga kita mau mengikuti mereka dan membuat kita sama seperti mereka.

Kecenderungan anak-anak hafal akan lirik lagu dewasa dalam hal ini lagu Korea pada khususnya pada anak-anak siswi di SD Negeri 17 Kuningan hampir keseluruhan anak-anak menjawab hafal lagu Korea tersebut walaupun diantaranya ada yang hanya sedikit mengetahui dan bisa menyanyikan lagu Korea, Jadi dapat disimpulkan bahwa anak-anak cenderung mengetahui dan hafal terhadap lagu BlackPink, walaupun diantaranya ada juga yang mengatakan tidak hafal lagu tersebut. Berdasarkan hal yang sama, ini serupa dengan apa yang diungkapkan oleh Rizal (2016: 17) yang mengatakan bahwa lirik lagu yang menjurus ke arah dewasa meskipun liriknya berulang-ulang dan mudah dihafal malah menjadi satu nilai negatif bagi anak usia 3-5 tahun 
yang belum mengetahui apa-apa kemudian dapat melantunkan lirik lagu yang dia sendiri tidak mengetahui makna dari lagu yang dia nyanyikan. Ini akan berdampak pada pandangan masyarakat dan perilaku sang anak ke depannya.

Dalam hal anak-anak memahami arti dan makna lagu dewasa dalam hal ini lagu Korea, berdasarkan hasil penelitian yang dilakukan khususnya dari siswi di SD Negeri 17 Kuningan didapatkan hasil atas wawancara semua anak-anak menjawab tidak mengerti akan arti dan makna dari lirik lagu BlackPink tersebut. Selaras dengan hal tersebut, ini di pertegas kembali menurut Rizal (2016: 18) yang mengatakan bahwa mereka menyanyikan seperti tidak memikirkan respon dari teman-teman ataupun orang dewasa di sekitar mereka. Padahal jika lirik lagu dangdut yang setara dengan pikiran orang dewasa dinyanyikan oleh anak-anak dan didengar oleh orang dewasa menganggap orang tuanya tidak membatasi apa yang patut didengar dan diucapkan oleh sang anak di lingkungan masyarakat khususnya. Karena dengan begitu karakter sang anak menjadi buruk karena perkataan dari nyanyian yang mereka tentunya tidak mengetahui makna dari lirik lagu dangdut yang mereka ucapkan.

Kemudian dari motivasi atau dorongan menyukai lagu BlackPink yang mempengaruhi dalam menyukai lagu dewasa berdasarkan jawaban yang diperoleh dari anak-anak khususnya siswi di SD Negeri 17 Kuningan adalah karena adanya pengaruh dorongan teman, serta akibat rasa ingin tahu anakanak terhadap hal-hal yang menimbulkan daya tarik, yang keduanya tersebut saling mendominasi. Hal yang serupa dijelaskan kembali bahwa menurut Gabriel Tarde dalam Gerungan (2004:33) dalam Sofianita dan Harti (2015) berpendapat bahwa semua saling berhubungan sosial (sosial interaction) itu berkisar pada proses imitasi, bahkan semua pergaulan antarmanusia itu menurut pendapat ini hanyalah proses imitasi itu. Imitasi adalah contohmencontoh, tiru-meniru, ikut-mengikuti, dan perkembangan proses imitasi dalam masyarakat sebagai rangsangan pikiran. Maka hal-hal yang diimitasi itu harus mendapat perhatian individu terlebih dahulu agar dapat diimitasi, selanjutnya terdapat sikap menjunjung tinggi atau mengagumi hal-hal yang akan diimitasi, dan terdapat pengertian yang cukup pada orang-orang 
terhadap hal-hal yang akan di imitasi itu, dan hal ini bergantung pula kepada tingkat perkembangan individu, kepada taraf intelejensinya dan kepribadian pada umumnya. Teman sebaya termasuk didalamnya karena salah satu pendorong untuk memasuki suatu kelompok agar kita diterima oleh di dalam lingkungan mereka kita harus bergaya seperti mereka, mengikuti perilaku sosial remaja, sehingga kita mau mengikuti mereka dan membuat kita sama seperti mereka.

Berdasarkan deskripsi hasil penelitian di atas, untuk itu peneliti akan memberikan uraian yang berisi penjelasan masalah dari proses kognitif pada anak yang akan disajikan dalam bagan berikut:

Gambar 6. Proses Imitasi Kognitif Anak

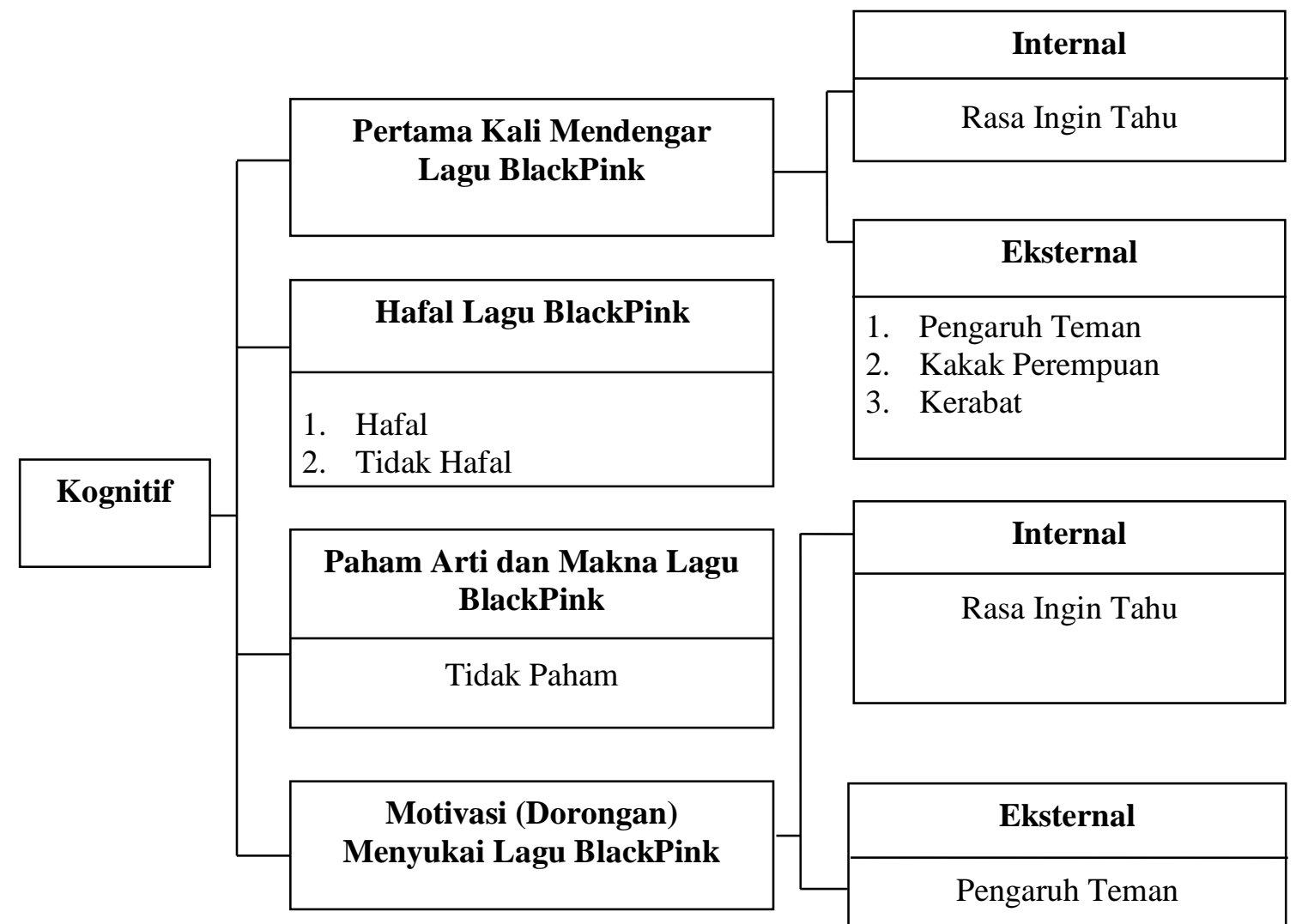


Gambar 6 di atas menjelaskan, dari data kognitif yang telah diuraikan, didapatkan hasil penelitian dari proses kognitif terhadap lagu BlackPink adalah: 1. Pertama kali mendengar lagu BlackPink diantaranya ada dua faktor, antara lain 1) faktor internal: keingintahuan anak mengenai lagu BlackPink, 2) faktor eksternal: di antaranya dari (1) pengaruh teman, (2) kakak perempuan, dan (3) kerabat yang memutar lagu BlackPink yang terdengar oleh mereka sendiri. 2. Hafal lagu BlackPink: mayoritas (1) anak hafal terhadap lagu BlackPink, walaupun diantaranya ada juga yang (2) tidak hafal. 3. Paham arti dan makna lagu BlackPink: semuanya kompak mengatakan bahwa tidak mengerti arti dan makna dari lirik lagu BlackPink tersebut. 4. Motivasi (dorongan) yang menyukai lagu BlackPink diantaranya ada dua faktor, 1) faktor internal: yaitu faktor rasa ingin tahu. 2) faktor eksternal: yaitu faktor dari pengaruh temannya sendiri.

\section{b. Afektif}

Alasan/sebab anak-anak menyukai lagu dewasa, khususnya siswi di SD Negeri 17 Kuningan mengungkapkan bahwa mereka menyukai lagu dewasa khususnya lagu Korea yaitu BlackPink diantaranya dari sekian anak-anak yang menjawab, sebagian besar anak-anak beralasan menyukai lagu BlackPink adalah atas dasar karena kecanntikan para personelnya, ada juga yang hanya sebatas menyukai lagunya, menyukai akan dance/tarian gerakannya, dan lagu BlackPink tersebut enak untuk di dengar, khususnya untuk mereka sendiri. Seperti yang dijelaskan berdasarkan simpulan yang diuraikan menurut Wicaksono dan Utomo (2017: 93) bahwa lagu memiliki kekuatan untuk menarik perhatian pendengarnya, tak terkecuali anak-anak. Daya tarik lagu ini dihasilkan dari unsur lagu itu sendiri yang mampu mempengaruhi emosi pendengarnya. 
Kemudian pujian yang diberikan orang lain kepada anak-anak dari hafalnya lagu dewasa, atau salah satunya adalah lagu korea, pada anak-anak khususnya siswi SD Negeri 17 Kuningan, mereka cenderung dalam hafalnya lagu BlackPink tetapi mereka mengungkapkan bahwa tidak adanya unsur pengharapan akan penghargaan sosial yang diberikan orang lain kepada dirinya, apabila mereka berharap akan suatu penghargaan sosial yang di dapat dari orang lain pun, mereka tidak pernah sama sekali mendapatkan suatu pujian yang disini adalah suatu penghargaan sosial atas imitasi dari hafalnya lagu dewasa atau dari lagu BlackPink, karena di samping tidak berharap akan suatu bentuk pujian dalam hal ini penghargaan sosial yang orang lain berikan kepada mereka, bagi mereka menyukai dan hafal lagu tersebut, hanya untuk hiburan bagi diri mereka sendiri.

Berdasarkan deskripsi hasil penelitian di atas, untuk itu peneliti akan memberikan uraian yang berisi penjelasan masalah dari proses afektif pada anak yang akan disajikan dalam bagan berikut:

\section{Gambar 7. Proses Imitasi Afektif Anak}

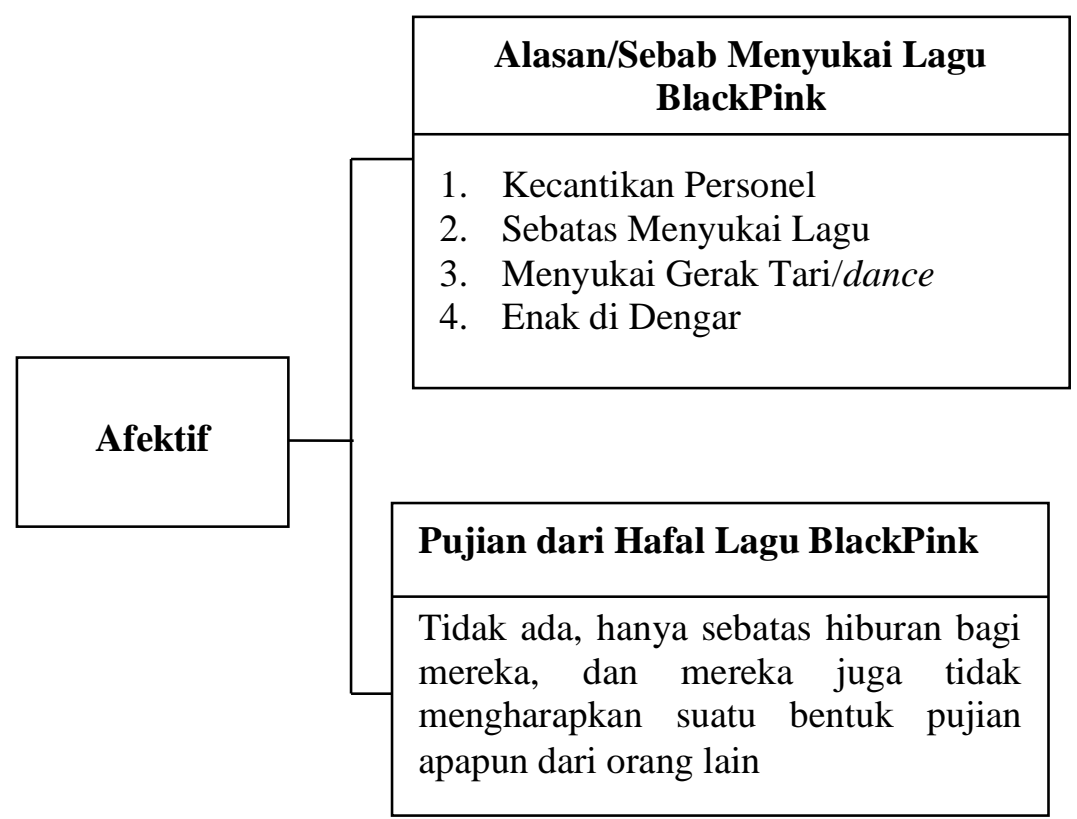


Gambar 7 di atas menjelaskan, dari data afektif yang telah diuraikan, didapatkan hasil penelitian dari proses imitasi terhadap lagu BlackPink diantaranya adalah: 1. Alasan/sebab menyukai lagu BlackPink: anak-anak menjawab (1) karena kecantikannya, ada juga yang hanya (2) sebatas menyukai lagu, (3) menyukai gerakan dance/tariannya, dan (4) enak didengar. 2. Pujian yang diterima dari hafalnya lagu BlackPink: bahwa tidak ada pujian yang anak dapatkan atas imitasi yang anak dapatkan dari hafalnya lagu BlackPink tersebut, karena mereka juga tidak mengharapkan sesuatu dari apa yang akan diberikan orang lain kepada mereka, dan itu semata-mata hanya untuk sebagai sarana hiburan bagi diri mereka sendiri.

Berdasarkan dari hasil proses kognitif dan afektif diketahui bahwa anak-anak di bagi menjadi 2 tipe dalam mengimitasi lagu dewasa, diantaranya akan dijelaskan dengan disajikan dalam bentuk sebuah bagan, yaitu sebagai berikut:

\section{Gambar 8. Tipe-Tipe Anak dalam Mengimitasi Lagu Dewasa}

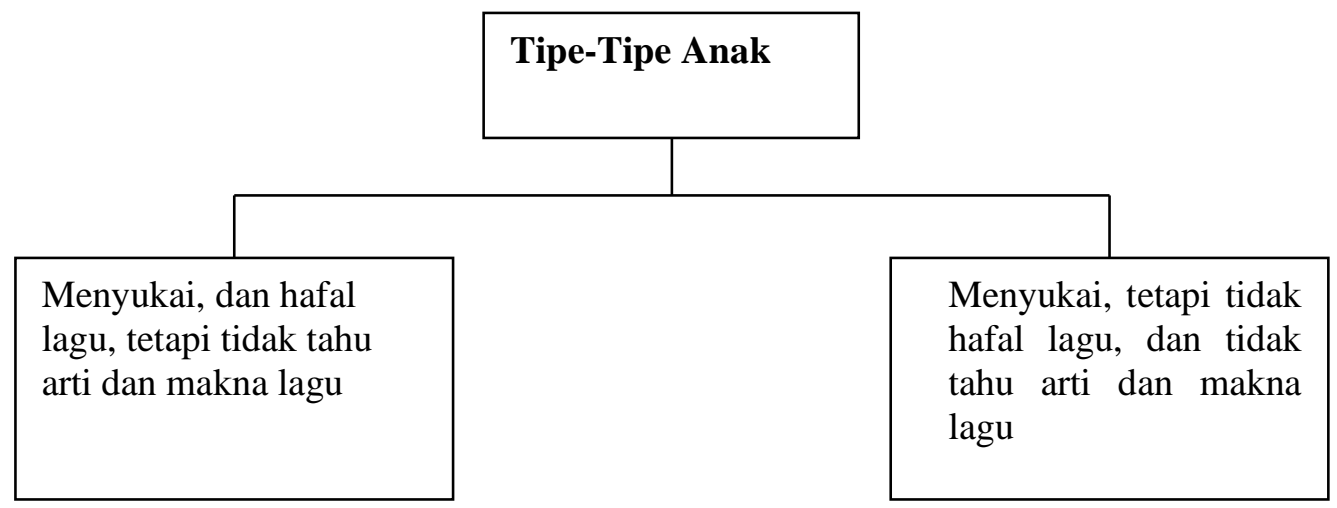


Gambar 8 di atas menjelaskan, tipe-tipe anak berdasarkan kombinasi antara pengaruh kognitif dan afektif yang anak rasakan, sehingga menemukan tipe-tipe anak yang diantaranya adalah: 1) anak menyukai lagu BlackPink, dan anak hafal lagu, tetapi tidak tahu atau tidak paham arti dan makna lagu yang dimaksud. 2) anak menyukai lagu BlackPink, tetapi anak tidak hafal lagu, dan juga tidak tahu atau tidak paham arti dan makna lagu yang dimaksud.

\section{c. Behaviorisme/Konatif}

Yang terakhir adalah dampak atas kecenderungan statement diberikan bahwa anak-anak menganggap dampat positif yang didapat menurut mereka khususnya dalam melatih cara berbicara mereka dalam berbahasa Korea, hafal akan lagu asing dalam hal ini adalah lagu Korea, melatih daya ingat anak dalam mengingat lirik lagu Korea, dan juga mereka juga bisa menyanyikan lagu Korea dalam hal ini lagu BlackPink, juga sebagai sarana hiburan bagi mereka sendiri, sedangkan untuk dampak negatif yang di dapat adalah diantaranya ada yang mengatakan bahwa dampak negatifnya adalah tidak bisa menghargai budaya sendiri, dikarenakan gaya berbusananya yang minim dalam penampilannya di setiap penayangannya. Menurut Fitri (2017) dalam hasil penelitiannya dari kesimpulannya dijelaskan bahwa berdasarkan analisis yang telah dilakukan sebelumnya didapatkan bahwa sisi sosial media mempunyai dua bagian yaitu positif dan negatif terhadap perubahan sosial anak. Mulai dari sisi negatifnya adalah anak-anak banyak yang menjadi anti sosial dimana mereka terlena oleh keasyikan berbincang dalam sosial media 
dibandingkan bertatap muka langsung dalam dunia nyata, hal lainnya adalah banyak juga yang terjebak menjadi pemalas dan boros demi melanjutkan keasyikan mereka dalam berbincang di sosial media. Hal positif yang di dapat juga banyak seperti kemudahan mengakses materi untuk tugas sekolah, bahan diskusi dari materi pelajaran di sekolah sampai memberikan pertemanan yang lebih luas bagi anak-anak yang sangat pendiam di dunia nyata.

Hasil menunjukan bahwasanya dampak positif yang anak-anak rasakan mereka bisa berbahasa korea, menyanyi lagu Korea, dan juga anak juga hafal dalam mengucapkan bait perbait dari lirik lagu BlacPink tersebut, ada juga yang menjawab sebagai hiburan untuk diri sendiri, tetapi untuk dampak negatif ada juga yang menjawab tidak bisa menghargai budaya dikarenakan memakai celana pendek dalam penayangannya baik itu video klip dari BlackPink itu sendiri maupun dari iklan yang ditampilkan di tv, diantaranya juga ada yang mengatakan tidak mengetahui akan dampak baik dan buruknya akan lagu BlackPink yang mereka sukai. Senada dengan hal dampak positif dari anak-anak yang bisa menyanyikan lagu BlackPink tersebut, hal ini diungkapkan juga oleh Ibu Intan selaku perwakilan dari orang tua di antara salah satu anak-anak tersebut, yang mengatakan bahwa:

"Kalo positifnya mungkin ya itulah karena dia memang satu di luar sekolah juga dia punya kegiatan nyanyi dan nari yah, ya itu mungkin dia akan nari yah, di les sih enggak, les khusus enggak cuman dia ikut paduan suara dia. Kalo negatifnya pasti ada yah, tapi enggak terpengaruh banyak sih dengan perilakunya sampe istilahnya meniru betul-betul meniru dari mulai pakean atau rambut itu enggak dia gitu. Sewajarnya aja paling punya poster, dan foto whatsaapnya, dia hanya suka aja seperti itu," (Ibu Intan, Wawancara pada tanggal 16 Maret 2019). 
Kemudian kembali didukung dengan jawaban yang serupa berdasarkan pendapat dari Ibu Heni Sulastri, dan Ibu Encih Sukaesih dari guru sekaligus wali kelas anak-anak kelas 3 dan 4, bahwa:

"Sebenarnya dari segi positifnya sedikit saja yah, sedikit banget, sedikit bangetnya karena disini paling anak menirukan gerakan mengingat dialog itu kan cukup untuk mengingat daya ingat aja yah, tapi yang lainnya menurut pendapat saya negatif sih banyaknya." (Ibu Heni Sulastri, Wali kelas 3, Wawancara pada tanggal 18 Maret 2019).

"Banyak sih, ada positifnya juga anak-anak tau mungkin itu syair lagunya, terus negatifnya banyak juga ya karena masih anak-anak, jadi diharapkan dari pada mencintai atau menyukai lagu dewasa lebih baikkan lagu yang sesuai dengan usianya," (Ibu Encih Sukaesih, Wali kelas 4, Wawancara pada tanggal 20 Maret 2019).

Didapatkan hasil berdasarkan statement yang diberikan baik dari anakanak, orang tua, guru dari wali kelasnya, adalah kecenderungan dampak yang didapat disini dampak positifnya adalah anak-anak cenderung bisa berbahasa Korea melalui lirik lagu, bisa menyanyikan lagu Korea, anak juga cenderung hafal lagu BlackPink, lalu membuat diri mereka merasa senang setelah mendengar lagu kesukaan mereka, dan juga mengasah kemampuan anak dalam mengingat sesuatu lewat lirik dari bahasa Korea yang anak ucapkan melalui lagu BlackPink, akan tetapi peneliti juga mendapatkan menurut anak itu sendiri yang mengatakan bahwa dampak negatifnya salah satunya ada yang mengatakan tidak bisa menghargai budaya sendiri, dikarenakan gaya berbusananya yang minim dalam penampilannya di setiap penayangannya.

Berdasarkan hasil penelitian, peneliti mendapatkan hasil proses imitasi anak dari data behaviorisme/konatif, dan diantaranya menghasilkan suatu 1 . Dampak positif diantaranya adalah: 1) pengetahuan: (1) bisa berbahasa Korea lagu melalui lirik lagu BlackPink, (2) hafal lagu BlackPink dalam hal ini 
adalah lagu Korea, (3) Melatih daya ingat dalam mengingat suatu bahasa asing, dalam hal ini lagu Korea. 2) kepuasan pribadi: (1) sebagai hiburan anak-anak, (2) anak cenderung bisa menyanyikan dan fasih melafalkan lirik lagu BlackPink dalam hal ini lagu Korea. 2. Dampak negatif: Tidak bisa menghargai budaya sendiri, dikarenakan gaya berbusananya yang minim dalam penampilannya di setiap penayangannya.

\section{E. KESIMPULAN}

Berdasarkan hasil penelitian yang dilakukan dapat peneliti tarik kesimpulan sebagai berikut: (1) Faktor Stimulus pada Anak dalam Proses Imitasi Lagu Dewasa di SD Negeri 17 Kuningan, di mana dalam mempengaruhi stimulus anak dapat diketahui anak-anak di SD Negeri 17 Kuningan cenderung menggunakan media sosial/aplikasi YouTube dan Instagram dalam mengakses internet untuk mendengarkan lagu Korea khususnya lagu BlackPink. Kemudian durasi durasi anak dalam menggunakan internet dapat diklasifikasikan menjadi beberapa bagian diantaranya, anak menggunakan internet dengan durasi $\leq 1$ jam dengan ketentuan waktu yang biasanya hanya sesaat anak memutarnya, yaitu dalam hitungan menit, dan sampai durasi video lagu BlackPink tersebut habis; selanjutnya anak menggunakan internet dengan durasi 1-3 jam dengan penggunaan batas wajar anak dalam hitungan jam mengakses internet yang tidak lebih dari batas waktu 3 jam dalam sehari; dan terakhir penggunaan berlebih/di luar batas normal dengan durasi $\geq 3$ jam, yaitu pengunaan akses berlebih anak dalam menggunakan internet khususnya penggunaan media sosial dengan durasi lebih dari 3 jam, sampai daya baterai gadget terkuras habis. Selanjutnya ternyata anak juga selain mengetahui lagu Korea dalam hal ini lagu BlackPink dari media sosial, anak juga mengetahuinya melalui media massa salah satunya dari media televisi yang disaksikan, diantaranya dari tayangan 
iklan, dan konser yang ditayangkan di televisi. Kemudian aspek lingkungan juga turut berperan dalam mempengaruhi stimulus anak, yaitu dari lingkungan sekitar tempat anak tersebut berada, khususnya dari pengaruh keluarga dalam hal ini kakak perempuan/saudara perempuan mereka, teman sebaya mereka, dan dari tetangga di lingkungan rumah tempat tinggal mereka dalam mengenalkan lagu BlackPink, tetapi dalam memperkenalkan lagu BlackPink anak juga dalam dirinya cenderung sebagai orang yang mempengaruhi orang lain dalam hal ini mempengaruhi orangdisekitarnya khususnya dalam keluarga mereka sendiri. (2) Faktor Kognitif dan Afektif pada Anak dalam Proses Imitasi Lagu Dewasa di SD Negeri 17 Kuningan, dalam proses imitasi kognitif, anak cenderung pertama kali terpapar lagu Korea dalam hal ini lagu BlackPink mengetahui dari temannya, keluarga dan kerabatnya, yang kemudian terdorong dari rasa keingintahuan yang tinggi dari diri mereka. Selanjutnya anak juga cenderung hafal menyanyikan lagu Korea khususnya lagu BlackPink, walaupun diantaranya ada juga yang tidak hafal. Anak yang terimitiasi cenderung tidak mengerti dari arti dan makna lagu yang dinyanyikannya. Kemudian yang melatarbelakangi anak tersebut mengimitasi lagu BlackPink ternyata anak termotivasi dari temannya, dan didorong rasa keingintahuan anak tersebut terhadap lagu. Kemudian dalam proses imitasi afektif, anak memiliki alasan dalam dirinya menyukai lagu BlackPink diantaranya karena menganggumi kecantikan para personelnya, menyukai lagunya, menyukai dance/tariannya, dan dari lagunya enak untuk didengarkan. Dalam mengimitasi lagu BlackPink anak tidak memiliki keinginan untuk mendapatkan pujian dalam hal ini penghargaan sosial, bila anak mengharapkan juga mereka tidak pernah mendapatkan pujian dari siapapun, karena bagi mereka yang terpenting adalah lagu tersebut enak untuk didengar, dan hanya sebagai sarana hiburan bagi diri mereka sendiri. (3) Hasil Temuan Penelitian di SD Negeri 17 Kuningan, dalam 
penelitian ini ditemukan bahwa teman-teman dari anak yang terimitasi mayoritas menggunakan media sosial/aplikasi YouTube sebagai sarana mendengarkan lagu Korea dalam hal ini lagu BlackPink. Dari penggunaan media sosial yang ada, khususnya dalam mengunduh lagu Korea dalam hal ini lagu BlackPink selain menggunakan YouTube, diantaranya ada juga yang mencari melalui google, melalui website unduhan gratis, dan ada yang melalui aplikasi salah satunya adalah aplikasi Snaptube. Berdasarkan dari aspek kognitif dan afektif ditemukan, anak dapat diklasifikasikan berdasarkan dari proses imitasi yang dilakukannya, yaitu berupa tipe-tipe anak dalam mengimitasi lagu dewasa dalam hal ini lagu BlackPink, diantaranya anak menyukai lagu BlackPink, dan hafal lagu, tetapi tidak tahu atau tidak paham arti dan makna lagu yang dimaksud; kemudian anak menyukai lagu BlackPink, tetapi anak tidak hafal lagu, dan juga tidak tahu atau tidak paham arti dan makna lagu yang dimaksud. Kemudian dari aspek proses-proses imitasi yang ada, didapatkan hasil yang berupa dampak positif dan negatif, diantaranya dampak positifnya anak fasih melafalkan bahasa Korea, hafal lagu Korea, melatih daya ingat dalam mengingat lirik lagu berbahasa Korea, dan juga sebagai sarana hiburan bagi diri mereka sendiri, dan juga diri mereka bisa menyanyikan lagu BlackPink tersebut, sedangkan dampak negatifnya adalah anak tidak bisa menghargai budayanya sendiri khususnya dari gaya berbusananya yang minim dalam penampilannya disetiap penayangannya.

\section{E. DAFTAR PUSTAKA}

Ahmadi, Abu. 2009. Psikologi Sosial. Jakarta: Rineka Cipta.

Ahmadi, Abu. 2009. Psikologi Sosial: Edisi Revisi. Jakarta: PT. Rineka Cipta.

Ardianto, Elvinaro. 2010. Metodologi Penelitian Untuk Public Relations: Kuantitatif dan Kualitatif. Bandung: Simbiosa Rekatama Media.

Azwar, Saifuddin. 2016. Sikap Manusia Teori dan Pengukurannya: Edisi Ke 2. Yogyakarta: Pustaka Pelajar.

Budi, Dhina Febrini Rosadnila. 2016. Pengaruh Terpaan Lagu Dewasa Terhadap Imitasi Bahasa Pada Anak-Anak (Studi pada Anak-anak SD Negeri 5 Tegineneng Kelas 4, 
5, dan 6). Skripsi. Program Studi Ilmu Komunikasi. Fakultas Ilmu Sosial dan Ilmu Politik. Universitas Lampung: http://digilib.unila.ac.id25140. Diakses pada tanggal 18 Desember 2018 pukul 20:00 WIB.

Bungin, Burhan. 2011. Penelitian Kualitatif: Komunikasi, Ekonomi, Kebijakan Publik, dan Ilmu Sosial Lainnya: Edisi Kedua. Jakarta: Kencana.

Effendy, Onong Uchjana. 2003. Ilmu, Teori dan Filsafat Komunikasi. Bandung: PT. Citra Aditya Bakti.

Endraswara, Suwardi. Metodologi Penelitian Foklor, Yogyakarta : Medpress, 2009.

Fitri, Sulidar. 2017. Dampak Positif dan Negatif Sosial Media Terhadap Perubahan Sosial Anak. Jurnal. Universitas Muhammadiyah Tasikmalaya. Vol. 1, No. 2, April 2017: http://journal.umtas.ac.id/index.php/naturalistic/article/view/5. Diakses pada tanggal 27 Maret 2019 pukul 07:00 WIB

Gerungan, W.A. 2010. Psikologi Sosial. Bandung: PT. Revika Aditama.

Gushevinalti. Adeni, Susri. dan Arrianie, Lely. 2014. Media Habit dan Interpretasi Anak Usia Dini Kota Bengkulu tentang Tayangan Media. Jurnal. Universitas Bengkulu. Vol. 8, No. 2, April 2014: http://sjournal.uii.ac.idjurnalkomunikasiarticledownload64775836. Diakses pada tanggal 3 Mei 2019 pukul 17:36 WIB.

Hamdi, Muhamad. 2016. Teori Kepribadian: Sebuah Pengantar. Bandung: CV. AlfaBeta.

http://warung-lyrics.blogspot.com/2018/06/lirik-lagu-blackpink-du-du-du-dan.html. Diakses pada tanggal 11 Januari 2019 pukul 19.00.

https://daerah.sindonews.com/read/904246/23/bahaya-anak-hafal-lagu-lagu-dewasa1411446989. Diakses pada tanggal 18 Desember 2018 pukul 20.00.

Hurlock, Elisabeth B. 1980. Psikologi Perkembangan: Suatu Pendekatan Sepanjang Rentang Kehidupan: Edisi Kelima. Jakarta: Penerbit Erlangga.

Ma'ruf, Amar. 2016. Upaya Pemerintah Dalam Mencegah Seks Bebas Pada Remaja Di Kelurahan Tipulu Kecamatan Kendari Barat Kota Kendari. Skripsi. Program Studi Dakwah dan Komunikasi. Fakultas Ushuluddin Adab dan Dakwah. Institut Agama Islam Negeri Kendari: http://digilib.iainkendari.ac.id123. Diakses pada tanggal 18 Desember 2018 pukul 20:00 WIB.

Mulyadi, Hang Teguh. 2016. Konflik Antara Badan Permusyawaratan Desa Dengan Kepala Desa Dalam Penyelenggaraan Pemerintahan Desa (Studi Kasus di Desa Slangit Kecamatan Klangenan Kabupaten Cirebon pada Tahun 2014-2016). Skripsi. Program Studi Ilmu Pemerintahan. Fakultas Sosial dan Ilmu Politik. Universitas Muhammadiyah Cirebon.

Nuraeni. 2017. Efektivitas Pemberian Stimulus Melalui Kegiatan Discovery Learning Terhadap Kemampuan Berpikir Kreatif dan Hasil Belajar Ppkn Siswa Di Smpn 3 Tanete Rilau Kabupaten Barru. Tesis. Program Studi Ilmu Pengetahuan SosialHukum dan Kewarganegaraan. Program Pascasarjana. Universitas Negeri Makasar: http://eprints.unm.ac.id/4328/1/NURAENI.pdf. Diakses pada tanggal 3 Mei 2019 pukul 08:38 WIB.

Rahmi, Amelia. 2013. Pengenalan Literasi Media Pada Anak Usia Sekolah Dasar. Jurnal. Semarang. Institut Agama Islam Negeri Walisongo. Vol. 8, No. 2, April 2013: http://www.journal.walisongo.ac.idindex.phpsawwaarticleview656. Diakses pada tanggal 26 Maret 2019 pukul 17:09 WIB.

Rakhmat, Jalaluddin. 2012. Psikologi Komunikasi. Bandung: PT. Remaja Rosdakarya. 
Rakhmawati, Istina. 2015. Peran Keluarga Dalam Pengasuhan Anak. Jurnal. Sekolah Tinggi Agama Islam Negeri Kudus. Vol. 6, No. 1, Juni 2015: http://journal.stainkudus.ac.idindex.phpkonselingarticledownload1037949.

Diakses pada tanggal 26 Maret 2019 pukul 19:30 WIB.

Rizal, Muhammad. 2016. Interpretasi Pesan Dalam Lirik Lagu Sebagai Perilaku Terbuka (Studi pada Orang tua pada Perilaku Anak-anak Setelah Senam Diiringi Lagu Remix Dangdut Vulgar di Superindo Kecamatan Mergangsan Yogyakarta). Skripsi. Program Studi Ilmu Komunikasi. Fakultas Ilmu Sosial dan Humaniora. Universitas Islam Negeri Sunan Kalijaga Yogyakarta: http://digilib.uinsuka.ac.id/24948/1/11730064_BAB-I_IV-atau-V_DAFTAR-PUSTAKA.pdf.

Diakses pada tanggal 27 Maret 2019 pukul 08:27 WIB.

Rochmawati, Weny. 2012. Perilaku Pemanfaatan Internet (Internet Utilization Of Behavior (Studi Deskriptif tentang Pemanfaatan Internet untuk Kepentingan Hiburan dan Akademik di Kalangan Anak-anak di Kota Surabaya). Jurnal. Universitas Airlangga. http://journal.unair.ac.id/download-fullpapersJURNAL_Weny\%20R. Diakses pada tanggal 26 Maret 2019 pukul 18:13 WIB.

Sahar, Arshano. 2014. Fenomena New Media 9Gag (Studi Observasi Terhadap Penggunaan Situs 9Gag dan Meme oleh Remaja) Makalah Non Seminar. Program Studi Ilmu Komunikasi-Hubungan Masyarakat. Fakultas Ilmu Sosial dan Ilmu Politik. Universitas Indonesia: http://lib.ui.ac.id/file?file=digital/20369079-MKArshano\%20Sahar.pdf. Diakses pada tanggal 4 Maret 2019 pukul 19:30 WIB.

Semiawan, Conny R. 2010. Metode Penelitian Kualitatif: Jenis, Karakteristik, dan Keunggulannya. Jakarta: PT. Gramedia Widiasarana Indonesia.

Severin, J Werner. Tankard, James W. 2011. Teori Komunikasi: Sejarah, Metode, \& Terapan di Dalam Media Massa, Edisi Kelima. Jakarta: Kencana.

Sobur, Alex. 2016. Psikologi Umum Edisi Revisi. Bandung: CV. Pustaka Setia.

Sofianita, Sania. dan Harti. 2015. Pengaruh Teman Sebaya (Peer Group) Terhadap Imitation Behavior Pembelian Aksesoris Pada Remaja (Studi Pada Siswi SMA Negeri 11 Surabaya). Jurnal. Program Studi Pendidikan Tata Niaga, Jurusan Pendidikan Ekonomi. Fakultas Ekonomi. Univesitas Negeri Surabaya. Vol. 3, No. 2 , 2015: https://jurnalmahasiswa.unesa.ac.id/index.php/jptn/article/view/12054/11236. Diakses pada tanggal 26 Maret 2019 pukul 21:02 WIB.

Sugiyono. 2017. Metode Penelitian Kuantitatif, Kualitatif, dan R\&D. Bandung: CV. Alfabeta.

Supriana, Heri. 2017. Pengaruh Media Massa Terhadap Citra Partai Politik. Skripsi. Program Studi Pemikiran Politik Islam. Fakultas Ushuluddin dan Studi Agama. Universitas Islam Negeri Raden Intan: http://prepository.radenintan.ac.id30551SKRIPSI_LENGKAP_HERRI.pdf.

Diunduh pada tanggal 3 Mei 2019 pukul 20:24 WIB.

Watie, Errika Dwi Setya. 2011. Komunikasi dan Media Sosial (Communications and Social Media). Jurnal. Dosen Jurusan Ilmu Komunikasi Universitas Semarang. Vol. 3, No. 1, Juli 2011: http://journals.usm.ac.id/index.php/themessenger/article/viewFile/270/172. Diakses pada tanggal 3 Mei 2019 pukul 09:07 WIB.

Wicaksono, Refi Yunanda. Utomo, Udi. 2017. Daya Tarik Lagu Bagi Anak Usia Dini (Studi Kasus Di TK Pertiwi Singodutan). Jurnal. Program Studi Sendratasik. Fakultas Bahasa dan Seni. Universitas Negeri Semarang. Vol. 6, No. 2, Desember 
2017: https://journal.unnes.ac.id/sju/index.php/jsm/article/download/17455/9846. Diakses pada tanggal 27 Maret 2019 pukul 10:41 WIB.

Yuliarti, Monika Sri. 2015. Komunikasi Musik: Pesan Nilai-Nilai Cinta Dalam Lagu Indonesia. Jurnal. Universitas Sebelas Maret. Vol. 12, No. 2, Desember 2015: https://www.researchgate.net/publication/313829558_Komunikasi_Musik_Pesan_ Nilai-Nilai_Cinta_dalam_Lagu_Indonesia. Diakses pada tanggal 6 Maret 2019 pukul 12:21 WIB.

Yuliyatun. 2012. Pengaruh Lingkungan Sosial dan Motivasi Belajar Terhadap Prestasi Belajar Ekonomi Pada Siswa Kelas VIII MTS Al Irsyad Ngawi Tahun Ajaran 2011/2012. Naskah Publikasi. Fakultas Keguruan dan Ilmu Pendidikan. Universitas Muhammadiyah Surakarta: http://eprints.ums.ac.id/19252/15/11._NASKAH_PUBLIKASI.pdf. Diakses pada tanggal 3 Mei 2019 pukul 20:25 WIB. 